\title{
The Improvement of Madrasah Ibtidaiyah Achievement Through Principal's Transformational Leadership
}

\author{
Tazkiyatul Ala'i \\ Department of Educational Management \\ Universitas Negeri Surabaya \\ Surabaya, Indonesia \\ tazkiyatul.18011@mhs.unesa.ac.id
}

\begin{abstract}
This study aims to find out whether the Islamic Elementary School (Madrasah Ibtidaiyah) achievement can improve through principal's transformational leadership. The methodology of this research is descriptive qualitative which is designed to collect data and information in depth. Data collection is done using triangulation techniques that combine observation, interview, and documentation methods. Improving principals' transformational leadership progressing step by step, which can be realized by forming the ideas, building shared vision, power sharing, and gaining expertise and experiencing success. The results of the study show that the Madrasah Ibtidaiyah achievement can improve through principal's transformational leadership.
\end{abstract}

Keywords-improvement; madrasah ibtidaiyah achievement; transformational leadership

\section{INTRODUCTION}

Madrasah Ibtidaiyah is an Islamic educational institution that is equivalent to Elementary School where the principal's leadership is the key to the success and sustainability of the school achievements. Madrasah Ibtidaiyah have a vital role because they are educational institutions at the basic level that play a dual role, not only introducing science in a moderate manner but also transferring religious values at once, so of course management and professional are needed. In this case, the leadership of a good principal to manage Madrasah Ibtidaiyah is needed in the midst of the implementation of National Education System which has undergone significant changes.

The dual role in the Madrasah Ibtidaiyah is still far from expectations. Because the quality in Islamic schools are varies and most of them are apprehensive. This can be discussed from various aspects, both related to instrumental inputs such us curriculum, teaching staff, teaching materials, and related to environmental inputs such as graduates and absorption by the labor market. Therefore, the leadership of the principal is very influential in improving the quality of Madrasah Ibtidaiyah in order to achievement.

The principal of Madrasah Ibtidaiyah is an educational unit level education leader who must have a strong leadership base. For this reason, every principal Madrasah Ibtidaiyah must understand the key to successful leadership that covers; the importance of principal's leadership, effective Madrasah Ibtidaiyah leadership indicators, ideal principals' leadership models, teacher's expectations of the principal, and the principals' leadership ethics. These keys must be owned, and integrated into each individual principal of Madrasah Ibtidaiyah, in order to be able to carry out management and leadership effectively, efficiently, independently, productively, accountably and so as to make the Madrasah Ibtidaiyah achiever.

To reach a Madrasah Ibtidaiyah that achieves, a model of principal's Madrasah Ibtidaiyah acts as an agent of change that has exemplary in the followers also has a vision and mission far ahead to advance and reach expected madrasah achievement. As a manager at madrasah, the principal has a great duty and responsibility in making decisions. Principal as leaders in madrasah have a strategic role in efforts to improve the quality of graduates, who are able to show their fighting power and competitive nature in global competition.

There are several criteria in which the existence of an educational institution especially Madrasah Ibtidaiyah will gain recognition as an achievement madrasah from the public such as producing alumni with high academic values, being able to reach achievements in various championships, the teacher has a strong commitment to the task, the principal has good leadership, the climate of the madrasah life is passionate, the facilities and infrastructure are adequate, and also having a synergistic relationship with the community. For this reason, Madrasah Ibtidaiyah must be able to position themselves as a superior institution and truly become an agent of change that can produce output according to demands of the times.

The achievement of madrasah depends on the principal's leadership style used. One of leadership style that can be applied in madrasah is transformational leadership. There are some previous researchers that prove transformational leadership can improve school achievement such as: Yingxiu [1] entitled principals' transformational leadership in school improvement; Abdullah [2] entitled effect of transformational principal leadership style on teachers commitments and school achievement; Darwyan [3] titled the contribution of the madrasah headmaster transformational leadership, teacher 
teaching performance, and learning culture to the improvement of the Madrasah aliyah achievement in the DKI Jakarta province. Based on the results of research from several researchers above, school performance can improve through the principal's transformational leadership.

Based on the explanations above, this study aims to find out whether the Madrasah Ibtidaiyah achievement can improve through principal's transformation leadership.

\section{METHOD}

This study uses descriptive qualitative research approach. According to Noeng Muhadjir [4], qualitative research is more consistent, namely in accordance with the conditions in the field in obtaining the results of the description. Bryman and Bell [5] stated that qualitative research is a research that indicates the relationship between theory and research and usually emphasizes on how theories were generated. As a research strategy, qualitative research is inductivist, constructionist, and interpretivist, but qualitative researchers always don't subscribe to all three of these methods. Nurul Zuhriah [6] defines descriptive method is a method that describes the symptoms that exist at the time of study. Qualitative research is a research procedure that produces descriptive data in the form of written or oral words from observable people or actors.

Williams [7] stated that the qualitative study is data collection in a scientific background, with promising use the scientific method, done by a person or researcher. Cox, et al.[8] stated that the qualitative study having six features namely; (1) pay no mind the context, the situation (concern of the context); (2) natural level (natural setting); (3) man as an instrument (the human instrument); (4) data is descriptive (descriptive data); (5) the plan be about the same research with the observation (emergent design); (6) analysis of data is inductive (inductive analysis).

Data collection methods used in research at Madrasah Ibtidaiyah Miftahul Ulum III Pereng Kulon were interview, observation, and data verification [9]. Steps which must be passed in conducting the research were pre-research stage, during the field and after the field.

\section{RESULTS AND DISCUSSION}

\section{A. The Achievement of Madrasah Ibtidaiyah}

The theory underlying the Madrasah Ibtidaiyah achievement refers to the effective five factors model proposed by Jaap Scheerens, such as (1) the leadership of the principal madrasah is strong; (2) emphasis on achieving basic abilities; (3) the existence of a comfortable environment; (4) high expectations of student achievement; (5) regular assessment of the program made by students.

According to the Ministry of Culture Education, schools are said to be good or achievement if they have eight criteria: (1) students who enter are rigorously selected and can be accounted for based on academic achievement, psychological test and physical tests; (2) educational facilities and infrastructure are fulfilled and conducive to the learning process; (3) climate and supportive atmosphere for learning activities; (4) teachers and education staff have high professionalism and adequate level of welfare; (5) improvise curriculum so that it meets the needs of students who generally have a high learning motivation compared to their age students; (6) student learning hours are generally longer because of the demands of the curriculum and student learning needs; (7) the learning process is more qualified and accountable to students and guardians of students; and (8) superior schools benefit the environment.

\section{B. The Principal's Transformational Leadership}

Transformational leadership is defined as a leadership approach that causes change in individuals and social systems. In its ideal form, it creates valuable and positive change in the followers with the end goal of developing followers into leaders. Enacted in its authentic form, transformational leadership enhances the motivation, morale and performance of followers through a variety of the mechanisms. These include connecting the follower's sense of identity and self to the mission and the collective identity of the organization; being a role model for followers that inspires them; challenging followers to take greater ownership for their work; and understanding the strengths and weaknesses of followers, so the leader can align followers with tasks that optimize their performance.

According to Burns [10], transforming leadership is a process in which leader and followers help each other to advance to a higher level of morale and motivation. The transforming approach creates significant change in the life of people and organizations. It redesigns perceptions and values, and changes expectations and aspirations of employees.

Leithwood have found that transformational leaders in school gives emphasis to achieve three main objectives, namely to help teachers establish, expand, and maintain a professional work culture and the spirit of corporation, to foster the professional development of teachers and solve problems effectively.

Based on the opinion above, it can be concluded that transformational leadership includes attempts to change subordinates to do more positive or better than what is usually done which influences performance improvement.

One of the transformational leadership activities is transforming. Transformational leadership demands the ability of principals in communication, especially persuasive communication. The principal who is able to communicate with his community will be a supporting factor in the transformation process of supporting factors in the transformation process of his leadership. Conversely, leaders who are unable to communicate persuasively with their communities will be a barrier to the transformation of their leadership.

There are four leadership components of transformational leadership theory, which are: (1) charisma or idealized influence has the meaning that a transformational leader must be charisma who is able to "enchant" followers to follow the leader. In a concrete form, charisma is demonstrated through behavioral understanding of the organization's vision and 
mission, having a firm stance, commitment and consistency in every decision that has been taken, and respecting subordinates. In other words, transformational leaders become role models that are admired, valued, and followed by their subordinates; (2) inspirational motivation means the character of a leader who is able to apply high standards but at the same time is able to encourage followers to reach these standards. Such characters are able to arouse high optimism and enthusiasm from followers. In other words, transformational leaders always inspire and motivate their followers; (3) intellectual stimulation the character of a transformational leader who is able to encourage his followers to solve problems carefully and rationally. In addition, this character encourages followers to find new ways that are more effective in solving problems. In other words, transformational leaders are able to encourage (stimulate) followers to always be creative and innovative; (4) personal and individual attention means the character of a leader who is able to understand the individual differences of his followers. In this case, transformational leaders want and are able to hear aspirations, educate, and train followers. In addition, a transformational leader is able to see the potential achievements and evolving needs of his followers and facilitate them. In other words, transformational leaders are able to understand and respect followers based on the needs of followers and pay attention to the desires of high achievers and developing followers.

\section{The Improvement of Madrasah Ibtidaiyah Achievement through Principal's Transformational Leadership}

Transformational leadership [11] refers to leadership skills in principals who can pioneer the school to a new levels amid school development. Madrasah Ibtidaiyah does not always innovate smoothly. Differences in circumstances and factors make the process look different, sometimes progress, sometimes deadlock, and much worse is the opposite. Putting emphasis on transformational leadership, hopes that the principal could create conditions inspire all Madrasah Ibtidaiyah members with a higher level of leadership for madrasah improvement at the very time, finally makes Madrasah Ibtidaiyah get out of chaos and realize transition in difficulties. Thus, transformational leadership is an important quality of principals. However, principals who want to have transformational leadership can be faced with challenges from practical problems. Researcher working with the principals of Madrasah Ibtidaiyah Miftahul Ulum III, summarized the practice of transformational leadership improvement while watching the madrasah personally and discussing.

Based on Yingxiu Yan, improving transformational leadership requires a process; this process can be divided into three stages. The first stage is transformational leadership's embryonic stage. At this stage, the principal does not have a clear sense, and they cannot play the role of transformational leadership consciously and correctly. The principal in this field maybe not the new, but the one works for years in low ability and achievement. That does not mean they do not have transformational leadership literacy, maybe just because this literacy has no potential and cannot play the right role. This potential also encourages the principal to think about the madrasah development, proposed the strategy. But these thoughts and strategies may not be in accordance with the actual of madrasah, may not help to promote madrasah development. This situation shows that the principal under the transformational leadership's embryonic stage have the desire to develop the madrasah, but lack of ability to lead the development of the madrasah. Especially during the key points of the madrasah development when the school faces a turning point, the principal ability of principals is primarily performance in transformational leadership.

The second stage of transformational leadership is the basic formation stage. In this stage, the principal's transformational leadership has experienced a lot of development; they can think of the school consciously and rationally, and produce several new strategies, then use these strategies to achieve the goal of advancing the madrasah development. But during this period, principal's transformational leadership is immature. Although they are active in thinking and solving problems, their considerations are unintentional or different. They still cannot put the madrasah development into a dynamic and systematic situation, and their strategies may be less of gradual progress. That means schools experience difficulties in the country's sustainable development under the leadership of principal. Therefore, principal's thoughts are often questioned by the teachers and superiors. The principal's good desire may be subject to others' misinterpretation. So, during this period, we must understand and help the principal by improving their initiatives to encourage the principal's transformational leadership.

The third stage of transformational leadership is the mature stage. At this stage, principals have been able to think freely about the school's development issues; they can continue put forward effective strategies to solve problems based on the actual situation of the madrasah; they can propose to think more about promotion at the peak of the madrasah development. Their design of developing madrasah development clearly performs like these: following the rules of madrasah management; look at the current situation of the madrasah in a dynamic and developing vision; design the future of the madrasah that are directed and systematic; strive to make the madrasah into a track of healthy development. The principal's transformational leadership maturity has an important influence on the development of madrasah. Under this influence, madrasah members can have a positive attitude; madrasah development can improve performance trends. Thus, the madrasah development and the principals' transformational leadership is a guarantee of the quality of integrated madrasah education.

It should be noted that transformational leadership does not indicate how long it has become a principal but by prioritizing significant options during school development. A principal who can always find effective solutions or improvement strategies is equipped with strong transformational leadership.

A principal should have strong transformational leadership that improve and helps the madrasah through difficult times to grow up as quickly as possible. In the collaboration, we realize that improving principals' transformational leadership progressing step by step, which can be realized by forming the 
ideas, building shared vision, power sharing, and gaining expertise and experiencing success.

1) Transformational leadership improvement is based on forming the ideas

The madrasah ideas determine the direction of achievement of madrasah, which is the management's awareness or trust after the principal's thinking activities about objective existence. But the formation of madrasah ideas is based on reflection on madrasah management problems. Principals can express the direction of improving madrasah and guide madrasah members from one stage to another with ideas. Madrasah ideas do not belong to the principal, but come from all members of the madrasah. If staff and members of the madrasah do not agree with the ideas, it is not possible to turn ideas into madrasah actions.

2) Building shared vision is the core of transformational leadership improvement

Vision is desired intention or blueprint made and shared with madrasah members, it can also inspire them to make joint efforts for certain interest [12]. If the madrasah members find strength and courage in shared vision, the core capability of the madrasah increases and highlights the personality of the madrasah. The vision of madrasah is far from the vision of the principal. It can do nothing but plan for future development strategies and madrasah. The principal's transformational leadership lies in leading members of the madrasah to build a shared vision and try it. The vision is focused and oriented, making the madrasah members struggle with clear goals and communication. Madrasah members can gain wisdom and grow together, when they try to understand and achieve their vision.

3) Gaining credence is the key to improve principals' transformational leadership

Gaining credence means a lot in the madrasah improvement. Madrasah improvement is the principal and madrasah members sincerely cooperate. If it doesn't have enough trust, the cooperation won't be successful. The first reason is that the members of the madrasah personnel are interrelated subsystems, seeing the relationship between systems and systems, needs to be built on the basis of mutual trust, mutual support. The second reason is that mutual trust between members of the madrasah reflects mutual respect between them, respect for others and respected by others is the inner needs of members.

4) Sharing power is the opportunity to improve the principal's transformational leadership

Principal's power is from the school members. Even though the principal is the administrative leader, if there is no school members' commissioned, he won't have any power [13]. Under the commissioned by members, the principal centrally uses the power to serve the members of the madrasah. In this case, when the principal uses his strength, he fulfills the obligation at the same time. Therefore, core problems in improving the effect of improving madrasah are concerned about the proper use of force and efficient allocation of interests. Sharing strength is an opportunity for improving madrasah. Sharing power means the expectations of the higher principal to the members, and he believes everyone is an extraordinary leader. This shows that the power of sharing means trust and respect, and that is the best way to encourage members.

5) Experiencing success is the lifeblood of transformational leadership improvement

Madrasah improvement aims to develop teachers and students. Progress and success should be possible for madrasah to gradually improve. Meanwhile, madrasah members can feel the pleasure of success in the process. In return, pleasure gets their trust in themselves and a sense of responsibility for the madrasah, resulting in a new driving force in the source of the feasibility of the madrasah. This circulation is the source of the feasibility of the madrasah. Principal transformational leadership should focus on giving members more opportunities for success. However, because of the members' different understanding of opportunities and abilities, when they take the opportunity, they can succeed, also may fail. Giving members more opportunities for success requires principals to improve transformative leadership in providing opportunities that are suitable for different members.

\section{CONCLUSION}

Principal's transformational leadership is the key to improve Madrasah Ibtidaiyah achievement. It can help the Madrasah Ibtidaiyah solve the problems pertinently and obtain various degrees of improvement on different stage. The process of forming transformational leadership includes: embryonic stage, basically formative stage and mature stage. The transformational leadership skills of principal can be seen in forming the ideas, building shared vision, power sharing, gaining credence and experiencing success. There are a lot of examples in the practice prove that the principals' leadership plays a key role in the Madrasah Ibtidaiyah achievement.

\section{REFERENCES}

[1] Y. Yang, "Principals' Transformational Leadership in School Improvement.," J. Acad. Adm. High. Educ., vol. 9, no. 2, pp. 77-83, 2013.

[2] A. Ibrahim, W. K. A. W. Mokhtar, S. Ali, and M. H. A. Simin, "Effect of Transformational Principal Leadership Style on Teachers Commitments and School Achievement," Int. J. Acad. Res. Bus. Soc. Sci., vol. 7, no. 5, pp. 518-527, 2017.

[3] D. Syah, "Kontribusi Kepemimpinan Transformasional Kepala Madrasah, Kinerja Mengajar Guru, dan Kultur Belajar Terhadap Peningkatan Prestasi Madrasah Aliyah Negeri Provinsi DKI Jakarta," J. Pendidik. dan Kebud., vol. 20, no. 2, pp. 173-186, 2014.

[4] M. Noeng, "Metodologi Penelitian Kualitatif.(edisi III)," Rakesarasin: Yogyakarta, 1996.

[5] E. Bell, A. Bryman, and B. Harley, "Business research methods: Oxford university press," 2018.

[6] E. K. Harahap, D. S. M. Jambi, D. L. Bi. U. I. N. S. Thaha, and S. Jambi, "Pemanfaatan Hasil Akreditasi Manajemen Madrasah Berprestasi, Mandiri, Islami dan Berdaya Saing Global (Studi di MAN Insan Cendikia Serpong)," J. Literasiologi, vol. 1, no. 1, p. 28, 2018.

[7] B. L. Wiliams, "Method for determining a type of memory present in a system." Google Patents, 12-Oct-2004.

[8] D. Cox, J. Little, D. O'Shea, and M. Sweedler, "Ideals, varieties, and algorithms," Am. Math. Mon., vol. 101, no. 6, pp. 582-586, 1994. 
[9] J. W. Creswell and J. D. Creswell, Research design: Qualitative, quantitative, and mixed methods approaches. Sage publications, 2017.

[10] J. Forester and S. R. Clegg, "Burns, JM (1978). Leadership. New York: Harper and Row," Leadersh. Q., vol. 2, no. 1, 1991.

[11] T. Vorbach, "Leading Multicultural Teams: A Qualitative Exploratory Study." Colorado Technical University, 2018.
[12] P. M. Senge, The fifth discipline: The art and practice of the learning organization. Broadway Business, 2006.

[13] J. Chapman and W. L. Boyd, "Decentralization, devolution, and the school principal: Australian lessons on statewide educational reform," Educ. Adm. Q., vol. 22, no. 4, pp. 28-58, 1986. 